\title{
Reflektoivat professionalistit
}

Donald Schön: The Reflective Practioner. How Professionals think in Action. Basic Books, Inc., Publishers. New York 1983. 374 sivua.

Aikuiskoulutusta ei Schönin kirjassa käsitellä. Liioin sitä ei voida pitää - tiukasti määritellen - tieteellisenä teoksena vaan pikemminkin laajalle lukijakunnalle suunnattuna "helpotettuna painoksena". Paikoitellen teoksen sosiologinen ja psykologinen tarkastelu lienee jopa selvää näennäistieteellisyyttä. Kuitenkin pidän teosta aikuiskouluttajalle ja varsinkin aikuiskoulutuksen tutkijalle hyödyllisenä: Kirjassa esitellään ja vertaillaan professionaalisten ammattien edustajien työssään soveltaman ajattelun tapoja ja tottumuksia. Tarkastelulla on selvät - joskaan ei ilmiselvät - yhteytensä esim. aikuiskouluttajan eettismoraaliseen työskentelyotteeseen tai vaikkapa näkemyksiin ammatillisen täydennyskoulutustarpeen luonteesta.
Kirja koostuu kolmesta osasta. Näistä ensimmäinen osa on keskeisin. Siinä yritetään vastata kysymykseen, mistä professionaalisten ammattien edustajien tietotaito koostuu ja mikä siinä on oleellisinta. Tietotaidon sisältö sinänsä ei ole tarkastelun kohteena vaan se, miten tietotaitoa sovelletaan työtoiminnassa esiin tulevien ongelmien ratkaisemiseen. Professionaalisilla ammateilla Schön tarkoittaa niitä ammatteja, joissa erilaisin interventioin pyritään muuttamaan vallitsevaa tilannetta suotuisammaksi. Määritelmä on varsin avoin ja sosiologisesti tarkasteltuna kyseenalainen. Sen mukaisia professionaalisia ammatteja ovat siten esim. kasvattajan, lääkärin, juristin ja liikkeenjohdon ammatit.

Professionalistien tietotaidon oleellisin piirre on Schönin mukaan joustava ja monitasoinen tapa lähestyä todellisuudessa (työtoiminnassa) esiintyviä ongelmia ja muutospyrkimyksiä. Niitä ei oteta annettuina vaan niitä muotoutetaan, jäsennetään ja hajotetaan yhä uudestaan. Tähän prosessiin liittyy usein myös omien taustaoletustensa kriittinen tarkastelu. Oheisia tietotaidon oleellisia piirteitä Schön kutsuu reflektiivisen ajattelun ominaisuuksiksi. Sen vastakohdaksi hahmotetaan tekniseen rationaliteettiin pohjautuva ajattelun tapa, jossa ongelma tai muutospyrkimys otetaan annettuna ja professionalistin tehtävä on ratkaista se valitsemalla sopivin ja tehokkain (toiminta)keino.

Kirjan toisessa ja kolmannessa osassa konkretisoidaan reflektoivan ja tekniseen rationaliteettiin pohjaavien ajattelun tapojen eroavuuksia sekä analysoidaan professionaalisten ammattien kehittymissuuntia ja yhteiskunnallisia velvollisuuksia. Ajattelun tapojen konkretisointi perustuu tapausesimerkkeihin psykoterapian, liikkeenjohdon, tuotekehittelyn ja kaupunkisuunnittelun alueilta. Esitys 
on selkeää ja havainnollista - nautittavaa ja juoksevaa lukemista. Kokonaan toinen asia on, onko näin voimakas ja mustavalkoinen tarkasteluote mielekäs. Tässä tapauksessa sitä voidaan perustella esityksen jäntevyyden avulla. Valitettavasti jäntevyys katoaa professionaalisten ammattien kehittymissuuntia ja yhteiskunnallisia velvollisuuksia analysoitaessa.

Schönin kirja on siten tasoltaan vaihteleva. Sen parasta antia on reflektiiviseen ja tekniseen rationaliteettiin pohjaavien ajattelun tapojen vertailu, joka kuitenkin myös osoittaa reflektiivisen ajattelun vaikeutta: todellisuus on taas kerran puristettu jäykkään dikotomiaan, mikä lienee usein ihmistieteille tyypillistä. Aikuiskasvatuksessa oiva esimerkki mustavalkoisesta ja arvovarautuneesta mutta kieltämättä selkeästä ja yksinkertaisesta dikotomiasta on puhe aikuisten opettamisen pedagogisesta ja andragogisesta mallista. Suomalaista aikuiskoulutusta ajatellen on Schönin teos tervetullut. Se antaa virikkeitä aiempaa monipuolisempaan ongelmanasetteluun. Teos on siten mielestäni soveltuva aikuiskasvatuksen yliopistolliseksi kurssikirjaksi (syventävät opinnot).

Juha Varila 